\title{
КОНКУРЕНТОСПОСОБНОСТЬ СТРАН РИК В НОВЫХ УСЛОВИЯХ ДИАЛЕКТИКА ПОНЯТИЯ
}

Перская В.В., Эскиндаров М.А. Конкурентоспособность национального хозяйства в условиях МногополярностИ: Россия, Индия, Китай. М: Экономика, 2015. 219 с.

В сегодняшнем насыщенном научно-информационном пространстве сложно найти исследования, совмещающие различные теоретические подходы и ракурсы в отношении явлений, рассматриваемых обычно в рамках отдельных трудов. Монография известных экономистов В.В. Перской и М.А. Эскиндарова обращает на себя внимание прежде всего соединением в предмете анализа понятий «конкурентоспособность» и «многополярность», что нельзя считать традиционным: тема многополярности современного мира первоначально освещалась в политологии и теории международных отношений, в то время как категория конкурентоспособности является преимущественно экономической. Междисциплинарность тематики монографии естественным образом предопределила и логику исследования, его инструментарий и научно-теоретическую основу.

Концепция многополярности активно обсуждается в трудах российских и зарубежных специалистов. Существуют и альтернативные подходы к оценке расстановки сил на мировой арене, обосновывающие неизбежность сохранения монополярности и необходимость для стран адаптации к существующему миропорядку. Однако для авторов рецензируемой монографии реально наблюдаемый процесс отхода от доминирования одной державы в международных отношениях выступает важнейшим фактором, меняющим сущность основных слагаемых конкурентоспособности национальных экономик в современных условиях.

Научная смелость исследователей не может не вызывать уважения: тематика национальной конкурентоспособности прорабатывается ведущими международными организациями и научными школами на протяжении многих лет. Сложилась и устоялась система методик расчетов международными организациями и хозяйствующими субъектами рейтингов конкурентоспособности для отдельных государств, которые в определенной степени оказывают психологическое давление на транснациональные и национальные компании, оперирующие в этих странах. Политические взаимоотношения также во многом зависят от системы рейтингов конкурентоспособности. Научное обоснование необходимости внесения корректировок в базовую концепцию конкурентоспособности под влиянием новых реалий международных отношений, на наш взгляд, заслуживает внимания со стороны не только научной общественности, но и структур, составляющих рейтинги.

При очевидной невозможности построения универсальной концепции конкурентоспособности для различных этапов становления мирового хозяйства, нельзя не признать доминирования на протяжении последних двадцати лет теории американ- 
ского ученого М. Портера. В монографии В.В. Перской и М.А. Эскиндарова на базе исследования основных положений этой теории обосновывается необходимость ее модификации в условиях перехода к многополярности с учетом характера и направленности современных глобализационных процессов.

Анализируя неолиберальные взгляды на глобализацию мирового хозяйства, авторы отмечают снизившуюся роль исследования реального сектора в данном направлении научной мысли, а также фетишизм финансов и биржевой активности. Подчеркивается необходимость более полного учета реальных экономических процессов в оценке национальной конкурентоспособности, что позволит скорректировать само понятие и применяемые критерии оценки.

Одной из успешно решенных задач исследования можно считать выявление факторов конкурентоспособности национальной экономики на современном этапе. Авторы считают, что они формируются главным образом на мезоуровне, по территориально-отраслевому принципу. Именно этот посыл позволяет логически выстраивать алгоритм модификации базовой теории конкурентоспособности в условиях перехода к многополярности и, в свою очередь, предложить критический анализ подходов к рассмотрению состояния национальной конкурентоспособности как инструмента для глобального развития, а не для обеспечения благосостояния своих граждан (подход, доминирующий в условиях монополярности).

В монографии обосновывается растущая роль региональной интеграции как инструмента повышения национальной конкурентоспособности в процессе формирования новых полюсов сопряжения интересов. Региональные «поля», по терминологии авторов, не препятствуя ни развитию национальных хозяйств, ни углублению глобализации, уравновешивают геополитическую конфигурацию мира и формируют новую картину международного сотрудничества, для которой характерна усиливающаяся многомерность и растущая динамичность за счет более полного учета интересов отдельных стран. В разделе монографии, посвященном формулированию новых взглядов на содержание понятия национальной конкурентоспособности в условиях многополярности, В.В. Перская и М.А. Эскиндаров приходят к выводу о том, что регионализация международного сотрудничества способствует укреплению конкурентоспособности стран и, как результат, повышает устойчивость мирового хозяйства.

Подойдя вплотную к теме устойчивости мировой экономики на современном этапе, авторы не позволяют себе отвлечься на эту чрезвычайно важную для нынешнего периода проблему. Не менее убедительным можно считать включение в число рассматриваемых задач тематику сравнительного анализа роли государства, в том числе при формулировании стратегий модернизации для отдельных групп стран и определении национальной конкурентоспособности в условиях моно- и многополярности.

Отдельного внимания заслуживает взгляд авторов на инновационную и инвестиционную составляющие национальной конкурентоспособности, безусловно связанные между собой неразрывным единством, а также на социальную компоненту этого понятия. Делается вывод о том, что национальные экономические интересы не могут сводиться к повышению успешности ведения всех видов деловой активности предпринимателей, а должны, прежде всего, быть нацелены на повышение жизненного уровня населения страны в целом, улучшение качества жизни во всех его проявлениях. В этой связи исследователи считают, что в процессе обеспечения национальной конкурентоспособности в условиях перехода к многополярности будет неизбежно повышаться роль государства, которое должно обеспечивать высокую степень управляемости национальной экономики, быть способным адекватно формулировать стратегии и программы развития и добиваться их реализации. Авторы, однако, оговариваются, что под управляемостью ни в коей мере не понимается командное администрирование. Растущая 
роль государства видится как способность более полно обеспечивать согласованность действий хозяйствующих субъектов и самого государства для реализации общественно значимых программ развития страны с учетом внешних факторов.

Для сопоставительного странового анализа национальной конкурентоспособности, представленного во второй главе монографии, В.В. Перская и М.А. Эскиндаров в качестве объектов исследования выбрали страны, различающиеся по уровню и темпам экономического развития, по доминирующим стратегиям и средствам их реализации: США, Китай, Индию и Россию.

По мнению авторов, в США вызрело понимание неизбежности перехода к многополярной конфигурации мирового хозяйства, которое проявляется в использовании новых для экономической доктрины страны средств и методов сохранения и повышения национальной конкурентоспособности. Это, прежде всего, наметившееся изменение роли государства в экономике и общественной жизни, определенный поворот к развитию реального сектора, усиление воздействия на многосторонние регулирующие структуры для обеспечения своих интересов, а также определенное противодействие созданию и активизации дей- ствия региональных интеграционных объединений различных типов.

Конкурентные возможности России, Китая, Индии, напротив, во многом связаны с региональным сотрудничеством, с формированием и расширением региональных и субрегиональных альянсов при четком очерчивании национальных интересов и использовании имеющихся ресурсов.

Эти и другие положения монографии убедительно иллюстрируются статистическими показателями, представленными в форме, доступной для восприятия широкой аудиторией.

Наконец, хотелось бы отметить уважительное, бережное отношение авторов монографии к работам российских и зарубежных коллег, свойственное настоящим ученым. Серьезные критические замечания высказываются после глубокой проработки труда оппонента и неизменно с учетом положений, с которыми авторы согласны. Последнее, впрочем, не снижает остроту научной полемики по актуальной теме выработки критериев определения понятия и факторов национальной конкурентоспособности в условиях перехода к многополярности.

Лилия Ревенко доктор экономических наук 